\title{
Set Up of "Longitudinal Care" Paradigm in Contemporary Family Medicine and Community Nursing
}

\author{
Manuel Ortega-Calvo ${ }^{1^{*}}$ and Manuel Ángel Calvo-Calvo ${ }^{2,3}$ \\ ${ }^{1}$ Department of Medicine, CIBER-OBN ISCIII, University of Seville, Spain \\ ${ }^{2}$ University Hospital Virgen del Rocío of Seville, Spain \\ ${ }^{3}$ Department of Nursing, University of Seville, Spain
}

*Corresponding author: Manuel Ortega-Calvo, Ph.D., Family Physician, Associate Professor, Department of Medicine, CIBER-OBN ISCIII, University of Seville, Spain

\begin{abstract}
The paradigm constitutes the development of what is called "normal science". On the other hand, one of the essential characteristics of medical and nursing practices in primary health care $(\mathrm{PHC})$ is the longitudinal heed of human beings. William Rathbone VI was a merchant and businessman noted for his philanthropic work. In 1859 his appreciation for the services of a nurse, Mary Robinson, engaged to care for his dying wife, prompted him to campaign for a system of district nursing to enable the poor to benefit from similar care. Florence Nightingale advised him to establish a training home in Liverpool, which was completed by 1863. Regardless of who it may be, the longitudinal paradigm in today's primary care is of nursing and not medical source. The role of religious orders has been different from a historical point of view and it jumps the temporal limits of Late Modern Period of History.
\end{abstract}

\section{Keywords}

(MESH) Science, History of nursing, History of medicine, Caregivers, Continuity of patient care

\section{Introduction}

One of the essential characteristics of medical and nursing practices in primary health care $(\mathrm{PHC})$ is the longitudinal heed of human beings [1]. A widely accepted hypothesis in Europe and the Western world is that the beginning of contemporary PHC took place at the Alma-Ata Conference, which is now 40 -years-old $[2,3]$. However we think that the historical roots are further back. We follow in this hypothesis the works of powerful researchers in PHC such as Barbara Starfield [4],
Denis Pereira Gray [5] and Trisha Greenhalgh [6,7].

\section{Historical Framework of Paradigm Concept}

By the year 1962, Thomas Kühn, an American physicist who felt early vocation to the history of science, published a book that has become a true best seller of the specialty. "The structure of Scientific Revolutions" [8]. It first appeared as a monograph of the International Encyclopedia of Unified Science [9] to be subsequently published as a book. In his work, Künh defined the paradigm concept as the first known in the history of science.

The paradigm, in this way, constitutes the development of what Kühn calls "normal science", and as such is manifested through the textbooks of a science or discipline, by presenting the theories accepted by the scientific communities of each discipline, explaining them and comparing them, showing them through experiments and observations. The paradigm defines the methods, the problems that a discipline or field of research must legitimately address, to be bequeathed to future generations of scientists. Although the paradigm concept has had naggings it cannot be doubted that it is an excellent analytical tool for the study of the development of a discipline. That's why we use it in this paper.

\section{Victorian Era, the Rathbone Family and the Caregivers}

William Rathbone VI (1819-1902) was a merchant

Citation: Ortega-Calvo M, Calvo-Calvo MA (2018) Set Up of "Longitudinal Care" Paradigm in Contemporary Family Medicine and Community Nursing. Int Arch Nurs Health Care 4:102. doi. org/10.23937/2469-5823/15100102

Accepted: October 13, 2018: Published: October 15, 2018

Copyright: (c) 2018 Ortega-Calvo M, et al. This is an open-access article distributed under the terms of the Creative Commons Attribution License, which permits unrestricted use, distribution, and reproduction in any medium, provided the original author and source are credited. 
and businessman noted for his philanthropic and public work. He was an English Liberal politician who sat in the House of Commons at various times between 1868 and 1895 . Rathbone spent some time with various companies in Liverpool and London and in 1842 became a partner in the family company Rathbone Brothers and Co., general merchants of Liverpool. He is said to have regarded wealth and business success chiefly as a means to the achievement of public and philanthropic work.

In 1859 his appreciation for the services of a nurse, Mary Robinson, engaged to care for his dying wife, Lucretia, his first wife, prompted him to campaign for a system of district nursing to enable the poor to benefit from similar care; his involvement of Florence Nightingale (1820-1910) led to a close friendship [10]. She advised him to establish a training home in Liverpool, which was completed by 1863 , because Nightingale's epidemiological investigations showed the need of reforms and an educated nurse who could provide better healthcare [11]. They subsequently wrote regularly to each other, sharing ideas and experiences, and mutual encouragement [12]. Florence Nightingale had a profound impact on the early development of district nursing and also the foundation of the Queen's Institute in 1887 [13] (Figure 1).

In 1863, the Liverpool Training School and Home for Nurses was established, from which basis a district nursing system was implemented in Liverpool through the 1860 s and spread throughout the country [14]. William Rathbone VI's involvement with this scheme also made him aware of the poor state of the workhouse hospitals, and he did much to assist in the reform of the nursing in workhouses [15].

He married firstly Lucretia Wainwright Gair (1823-
1859). They had five children, but Lucretia died shortly after the birth of the fifth. She was lovely cared by Mary Robinson. Rathbone re-married on 6 February 1862 to Esther Emily Acheson Lyle (1832-1918). They had six children, including the campaigner and politician, Eleanor Rathbone and Emily Evelyn (Evie) (1865-1954) who married with her cousin Hugh Reynolds Rathbone. Emily Rathbone actively supported her husband's work in the establishment of District Nursing in Liverpool, and initiating a schools' nursing service in the city in 1895 (Figure 2).

\section{Discussion}

One of the researchers who first preferred the term "Iongitudinality" to the continuity of care was Barbara Starfield in her classic volume on primary care [16]. It had been showed before a greater satisfaction of patients with the continuity of health care [17]. As well, longitudinal care is inversely associated with mortality rates [18]. Nevertheless, the value of continuity of care has been strengthened by discontinuity research $[19,20]$. For all these reasons we think the concept or paradigm of "longitudinal care" is angular in contemporary health thought.

Although they have existed earlier historical figures such as Saint John God (1495-1550) [21] and Miguel Manara (1627-1679) [22] that upgraded the concept of health care in time, we think that the "contemporary nature" of longitudinal caregiver was born in Liverpool with the creation of the School of Community Nurses. We consider that the one who perceived first the shift of informal to formal caregiver was William Rathbone $\mathrm{VI}$ after the experience of the loss of his first wife and the evaluation of Mary Robinson's tasks. She was perhaps the first modern formal caregiver. The role of deacon-

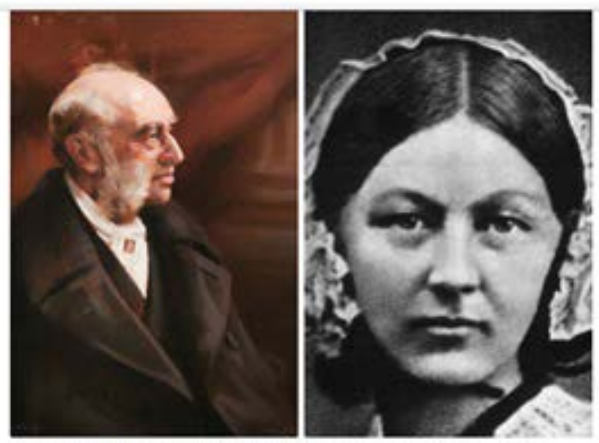

Longitudinal Care Paradigm Rising

Liverpool District Nursing School Foundation -1863.

William Rathbone VI and Florence Nightingale

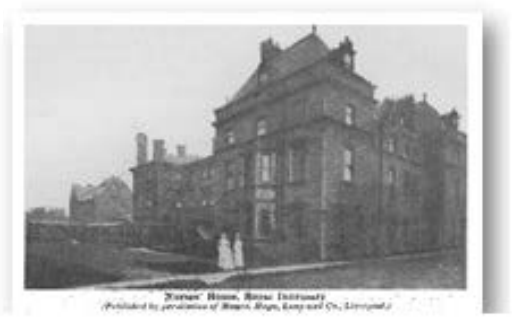

Figure 1: In 1863 a School of District Nursing was founded in Liverpool thanks to the collaboration and friendship between Rathbone and Nightingale. 


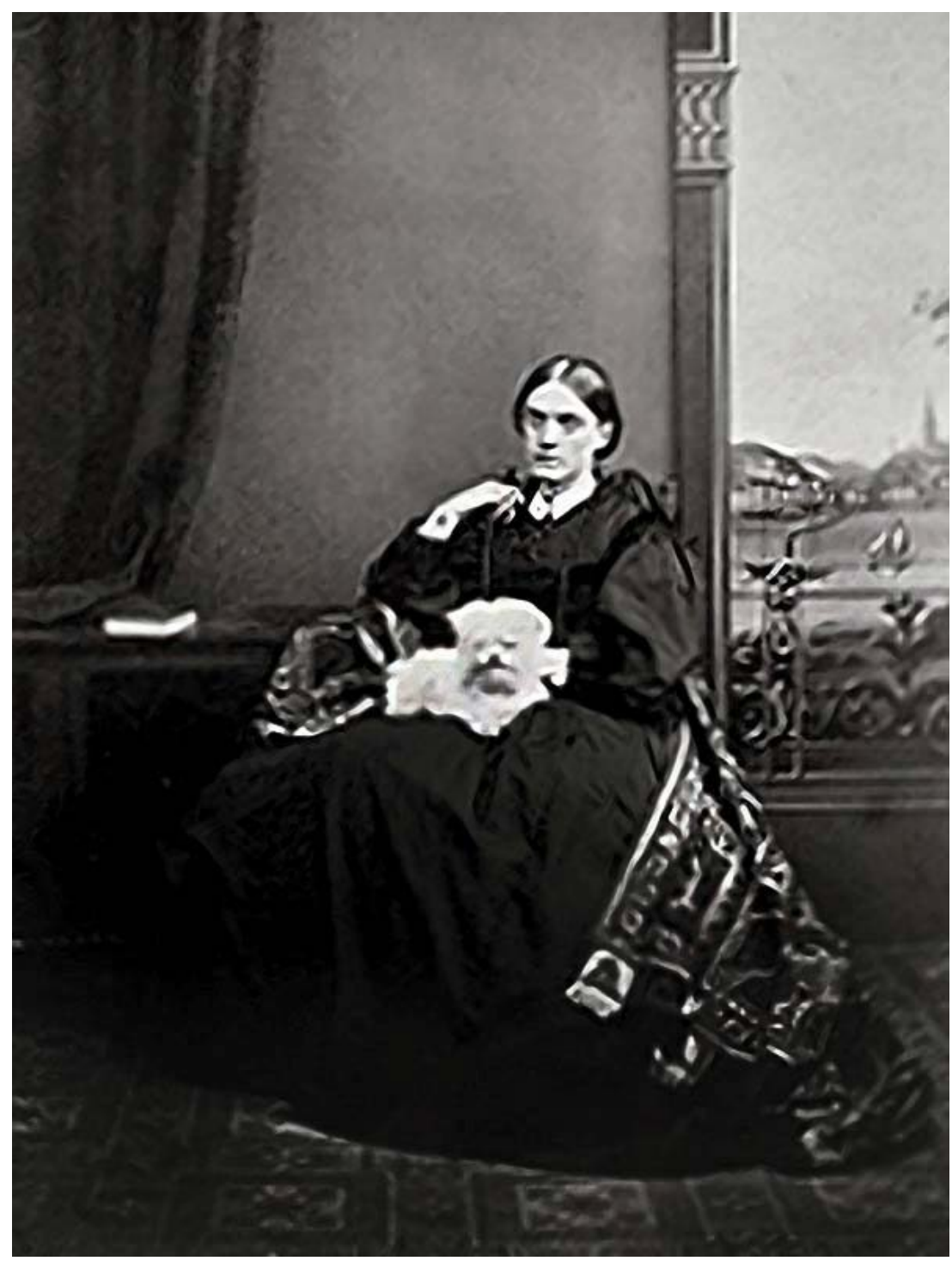

Figure 2: Emily Rathbone (Evie) (1865-1954). Lady Superintendent of District Nurses.

esses $[23,24]$ is something similar but different because they have a strong religious base [25]. The role of religious orders has been different from a historical point of view and it jumps the temporal limits of Late Modern Period of History. The longitudinal care necessitated by social issues and not spiritual or religious needs or motivations.

It is difficult to discuss the history of district nursing without a mention of the notorious fictional characters of Sarah Gamp and her colleague Betsy Prig portrayed by Charles Dickens [26], although sometimes he did it in too favorable terms [27]. In other Anglo-Saxon countries like Australia, district nursing was born somewhat later [28].

Regardless of who it may be, the longitudinal paradigm in today's PHC is of nursing and not medical origin. History should not only be a research [29] and reflective practice for nursing [30,31], it should also be for family medicine in this case $[32,33]$. The aim of contemporary history is to conceptualise, contextualise and historicise some aspect of the recent past or to provide a historical understanding of current trends or developments. The increase in the velocity of history means, among other things, that the 'present' becomes the 'past' more swiftly than ever before, especially in the hyper-connected society we live.

In summary, we defend in this article the hypothesis that the concept of longitudinality in contemporary primary care was beard during the late period of modern history (1863) in Liverpool. Its rational origin is a nursing enterprise. Over time, the longitudinal paradigm of care has become consubstantial with the specialties of Family Medicine [34] and Community Nursing [35].

\section{References}

1. Starfield BH, Simborg DW, Horn SD, Yourtee SA (1976) Continuity and coordination in primary care: Their achievement and utility. Med Care 14: 625-636.

2. Hixon AL, Maskarinec GG (2008) The Declaration of Alma Ata on its 30th anniversary: Relevance for family medicine today. Fam Med 40: 585-588.

3. Martín-Zurro A (2018) Alma Ata and family medicine: 40 years of desert crossing. Aten Primaria 50: 203-204.

4. Starfield B, Shi L, Macinko J (2005) Contribution of primary care to health systems and health. Milbank Q 83: 457-502. 
5. Pereira Gray D (1991) Research in general practice: Law of inverse opportunity. BMJ 302: 1380-1382.

6. Wieringa S, Engebretsen E, Heggen K, Greenhalgh T (2018) How knowledge is constructed and exchanged in virtual communities of physicians: Qualitative study of Mindlines Online. J Med Internet Res 20: e34.

7. Blanco Rubio C, de Francisco Montero C, González Hernández FJ, Adrada Bautista A, Gabaldón-Rodríguez I, et al. (2016) A brief overview of English primary care in the last half century. Rev Esp Salud Publica 90: e1-e8.

8. Kühn TS (1962) The Structure of Scientific Revolutions.

9. International Encyclopedia of Unified Science.

10. Monteiro LA (1985) Florence Nightingale on public health nursing. Am J Public Health 75: 181-186.

11. Kudzma EC (2006) Florence Nightingale and healthcare reform. Nurs Sci Q 19: 61-64.

12. Dixon S (2000) The archive of the Queen's Nursing Institute in the Contemporary Medical Archives Centre. Med Hist 44: 251-266.

13. Cohen IB (1984) Florence Nightingale. Sci Am 250: 128137.

14. Bickerton TH (1912) Liverpool, Past and Present. Br Med J 1: 29-37.

15. https://www.liverpoolpicturebook.com/2014/02/WilliamRathboneVI.html

16. Starfield B (1992) Primary care: Concept, evaluation and policy. Oxford University Press, New York.

17. Hjortdahl P (1992) Continuity of care: General practitioners knowledge about, and sense of responsibility toward their patients. Fam Pract 9: 3-8.

18. Hoertel N, Limosin F, Leleu H (2014) Poor longitudinal continuity of care is associated with an increased mortality rate among patients with mental disorders: results from the French National Health Insurance Reimbursement Database. Eur Psychiatry 29: 358-364.

19. Sweeney KG, Gray DP (1995) Patients who do not receive continuity of care from their general practitioner - are they a vulnerable group? Br J Gen Pract 45: 133-135.

20. Gray DP, Evans P, Sweeney K, Lings P, Seamark D, et al. (2003) Towards a theory of continuity of care. J R Soc Med 96: 160-166.
21. Fernandes-de Freitas G , Siles-González J (2008) Anthropology and caring in the view of Saint John of God. Index de Enfermeria 17: 144-148.

22. Calvo-Calvo MA (2016) Indications of professionalization in nursing in Spain in the seventeenth century according to hospital statutes in Seville. Aquichan 16: 513-525.

23. Kreutzer S (2010) Nursing body and soul in the parish: Lutheran deaconess motherhouses in Germany and the United States. Nurs Hist Rev 18: 134-150.

24. Schweikardt C (2010) The introduction of deaconess nurses at the German hospital of the city of Philadelphia in the 1880s. Nurs Hist Rev 18: 29-50.

25. Alvsvåg H (1981) Deaconesses versus Florence Nightingale. Sykepleien 68: 4-6.

26. Dickens C (1994) Martin Chuzzlewit. Wordsworth Editions Ltd, Hertfordshire, 390-455.

27. Morrison CM (2013) An oral history of district nursing in the Outer Hebrides 1940-1973. A Heroic Service? University of Manchester.

28. Madsen W (2013) Exploring the ethos of district nursing, 1885-1985. Contemp Nurse 44: 242-252.

29. Whitehead $D$ (2001) The case for researching the history of community nursing practice. Br J Community Nurs 6: 224229.

30. Smith KM, Brown A, Crookes PA (2015) History as reflective practice: A model for integrating historical studies into nurse education. Collegian 22: 341-347.

31. Holme A (2015) Why history matters to nursing. Nurse Educ Today 35: 635-637.

32. Carek PJ, Anim T, Conry C, Cullison S, Kozakowski S, et al. (2017) Residency training in family medicine: A history of innovation and program support. Fam Med 49: 275-281.

33. Pereira-Gray D (2001) Historical analysis: A new approach comparing publications from inside and outside the discipline over time. Med Educ 35: 404-408.

34. White ES, Pereira Gray D, Langley P, Evans PH (2016) Fifty years of longitudinal continuity in general practice: $A$ retrospective observational study. Fam Pract 33: 148-153.

35. Sakanashi S, Fujita K (2017) Empowerment of family caregivers of adults and elderly persons: A concept analysis. Int J Nurs Pract 23: e12573. 